\title{
PLATE IX.
}

Fig. 14. Sagittal section of head and part of prothorax of imago of Mononychus oulpeculus, slightly diagrammatized in order to bring into view esophageal and antennal muscles, etc.: am, antennal muscles; ant, antenna; $t r$, trachea ; $m$, esophageal muscles; oe, esophagus; $m p$, pharyngeal process of the mandible; hy, hypopharynx; l. labium; $t$, base of the abductor tendon of the mandible, with muscle attached; tut, tentorium; $g$. subesophageal ganglion; $b r$, cerebral ganglion: the frontal ganglion lies directly before it upon the esophagus; $p v$; proventriculus; $s . g l$, salivary gland.

Fig. 15. Mandible of sane, with its acductor $\left(t^{1}\right)$ and abductor $\left(t^{2}\right)$ tendons and muscles and its pharyngeal process $(m p)$ attached.

Fig. 16. A cross section of the beak of a young pupa of Mononycleus vulpeculus about midway its length : $f$, fat cell; the tendons of the mandibles $\left(t^{1}\right)$ lie farther from the middle line than those of the maxillae $(t)$, other lettering as in fig. 14 .

Fig. 17. Cross section of the beak of an imago of the same spectes, through the pharyngeal region, showing the swallowing apparatus of the pharynx; $m d$. $t$, tendons of the mandible; $m x . t$, tendons of the maxilla, other lettering as in fig. $\mathrm{I}_{t}$; four scales are represented in black, protruding through the chitin layer.

Fig. 18. Mandible of Balaninus nasicus with tendons and pharyngeal process ( $m p$ ) attached.

Fig. 19. Labium of same: $p$, palpus; $g l$, glossa.

Eurema risa in New Hampshire. - I have to record the capture of a male of this species at Alstead, N. H., Aug. 27, 1904. It was flying in upland meadow country at an altitude of about $\mathrm{t} 100$ feet, and five and a half miles from the Connecticut River. The specimen is fresh and uninjured. This appears to be the first recorded occurrence of the species in the western portion of the state. Previous records are almost strictly confined to the towns near the seacoast, though one is from the Merrimac valley.-JAMes A. Field. 

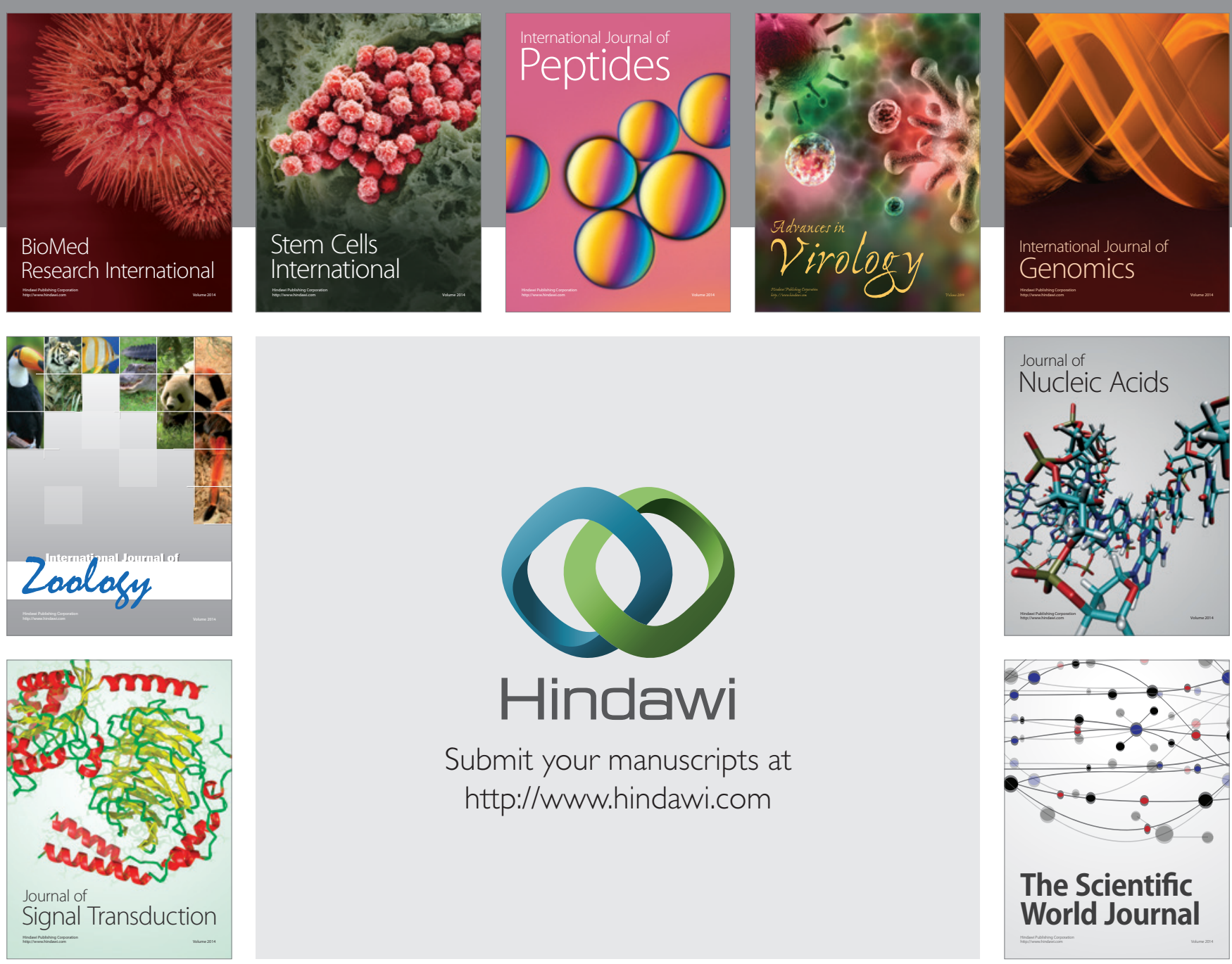

Submit your manuscripts at

http://www.hindawi.com
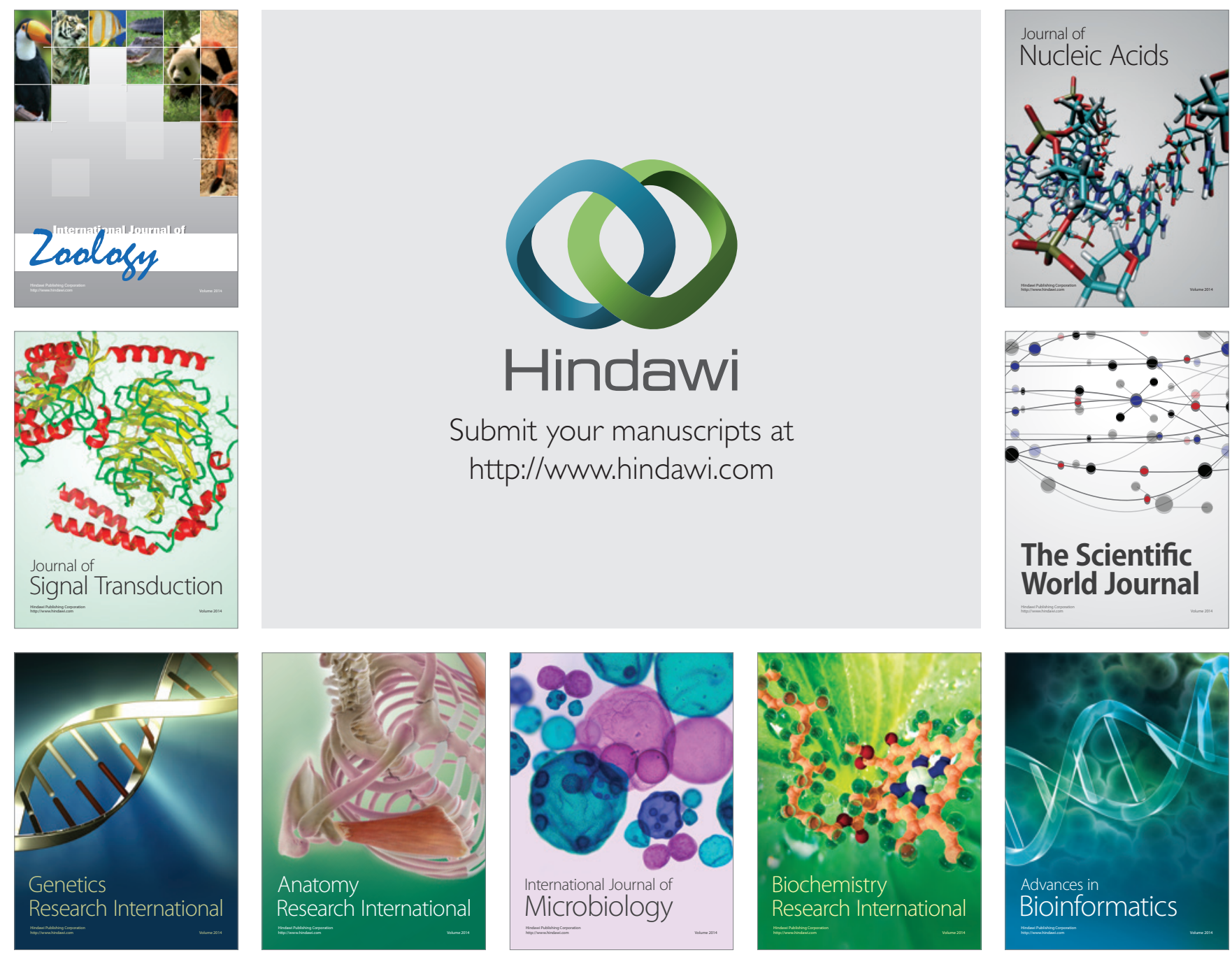

The Scientific World Journal
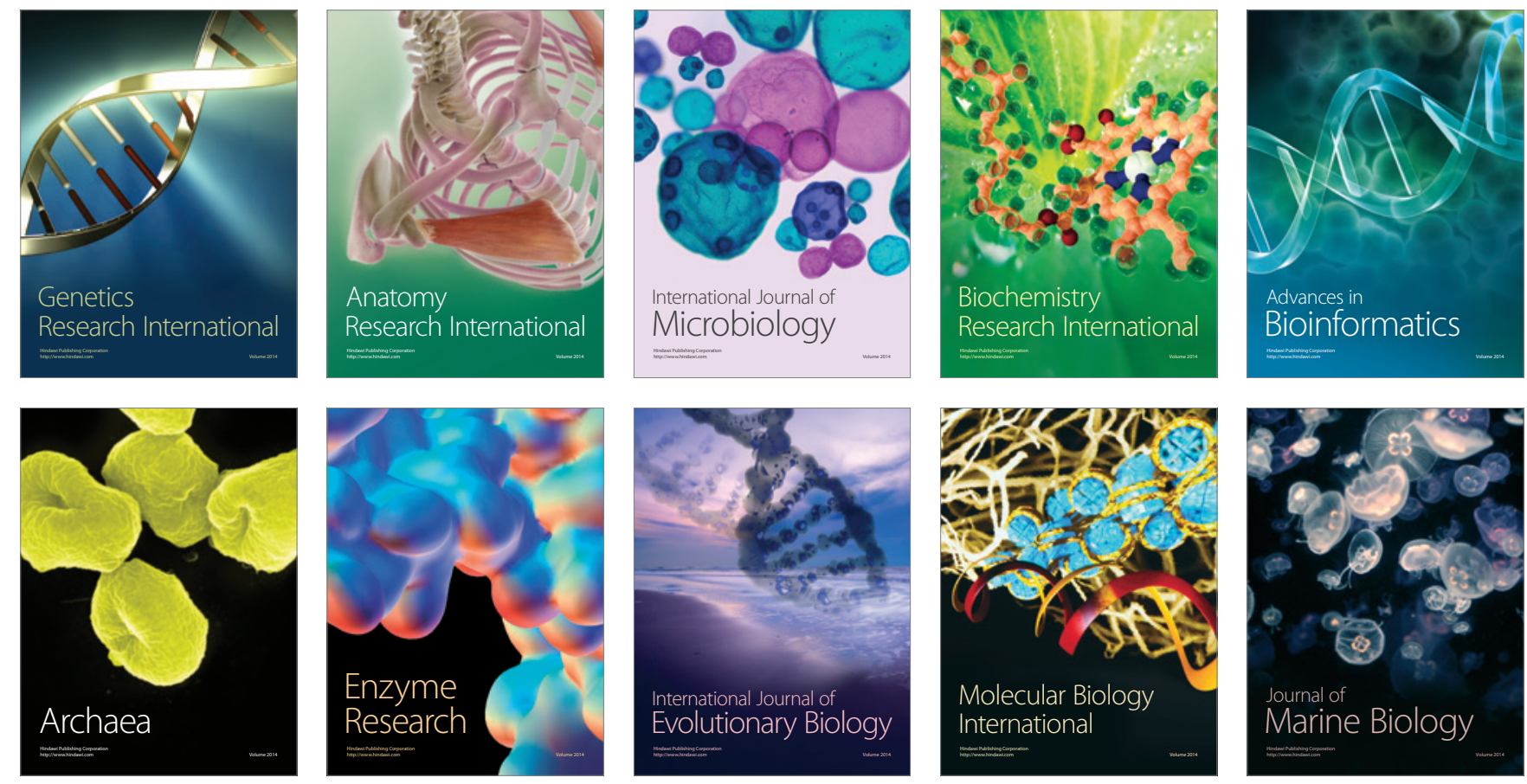